\title{
Reaction of popcorn lines (s7) cultivated in distinct phosphorus levels to Bipolaris maydis infection
}

\author{
Antonio Teixeira do Amaral Júnior'; Tathianne Pastana de Sousa Poltronieri²; Pedro Henrique Dias dos Santos²; \\ Marcelo Vivas $^{3}$; Ismael Fernando Schegoscheski Gerhardt'; Beatriz Murizini Carvalho ${ }^{1}$; Camila da Silva Freitas ${ }^{2}$, \\ Silvaldo Felipe da Silveira ${ }^{2}$
}

\begin{abstract}
${ }^{1}$ Universidade Estadual do Norte Fluminense Darcy Ribeiro - UENF, Laboratório de Genética e Melhoramento Vegetal-LMGV, Av. Alberto Lamego 2000 - Parque Califórnia - CEP: 28013-602 - Campos dos Goytacazes - RJ - Brasil; ${ }^{2}$ Universidade Estadual do Norte Fluminense Darcy Ribeiro - UENF, Laboratório de Entomologia e Fitopatologia - LEF, Av. Alberto Lamego 2000 - Parque Califórnia - CEP: $28013-602$ - Campos dos Goytacazes - RJ - Brasil; ${ }^{3}$ Universidade Estadual do Norte Fluminense Darcy Ribeiro - UENF, Laboratório de Engenharia Agrícola - LEAG, Av. Alberto Lamego 2000 - Parque Califórnia - CEP: 28013-602 - Campos dos Goytacazes - RJ - Brasil.
\end{abstract}

Autor para correspondência: Antonio Teixeira do Amaral Júnior (amaraljr@pq.cnpq.br)

Data de chegada: 10/03/2017. Aceito para publicação em: 12/04/2018.

$10.1590 / 0100-5405 / 176851$

\section{ABSTRACT}

Amaral Júnior, A.T.; Poltronieri, T.P.S.; Santos, P.H.D.; Vivas, M.; Gerhardt, I.F.S.; Carvalho, B.M.; Freitas, C.S., Silveira, S.F. Reaction of popcorn lines (s7) cultivated in distinct phosphorus levels to Bipolaris maydis infection. Summa Phytopathologica, v.45, n.1, p.18-22, 2019.

Popcorn culture is highly susceptible to helminthosporiosis (Bipolaris maydis) (h-Bm). The genetic breeding of this culture should prioritize resistance to $\mathrm{h}-\mathrm{Bm}$ and develop cultivars that offer greater crop sustainability, especially in soils with phosphorus (P) scarcity. $\mathrm{P}$-mineral is usually supplied to maize culture by the application of phosphate fertilizers, which are produced from mineral sources rich in $\mathrm{P}$, the natural reserves of which will be depleted in the medium term. With the aim of selecting popcorn genotypes resistant to h- $\mathrm{Bm}$ and with higher P utilization capacity, the present study evaluated h- $B m$ incidence and severity for 25 popcorn lines (S7) cultivated under high and low phosphorus conditions. There was a significant interaction between genotype (lines) and $\mathrm{P}$ fertilization for $\mathrm{h}-\mathrm{Bm}$ resistance, expressed as disease severity values in the first ear leaf. There was genetic variability for disease resistance. The incidence analysis identifies the lines L-65 L-69, L-70 and L-76 as potentially resistant genotypes, presenting low mean values of $\mathrm{h}-\mathrm{Bm}$. The severity analysis, however, presents L-69, L-76, P-3 and P-7 genotypes as potentially resistant in environments with fertilization and without fertilization. The obtained data show that the lines L-69 and L-76 had the best resistance performance in both environments. The genetic resistance to h- $\mathrm{Bm}$ can somehow correlate with the response to $\mathrm{P}$ fertilization at planting in soils with low natural fertility.

Keywords: Zea mays; Genetic resistance; Phosphate fertilizers.

\section{RESUMO}

Amaral Júnior, A.T.; Poltronieri, T.P.S.; Santos, P.H.D.; Vivas, M.; Gerhardt, I.F.S.; Carvalho, B.M.; Freitas, C.S., Silveira, S.F. Reaction of popcorn lines (S7) cultivated in distinct phosphorus levels to Bipolaris maydis infection. Summa Phytopathologica, v.45, n.1, p.18-22, 2019.

O milho-pipoca apresenta alta suscetibilidade a helmintosporiose (Bipolaris maydis) (h- $\mathrm{Bm})$. O melhoramento genético desta cultura deve priorizar a resistência a $\mathrm{h}-\mathrm{Bm}$ e desenvolver cultivares que ofereçam maior sustentabilidade ao cultivo, principalmente em solos com escassez de fósforo (P). O P-mineral normalmente é suprido à cultura do milho pela aplicação de adubos fosfatados, produzidos a partir de fontes de minério rico em $\mathrm{P}$, cujas reservas naturais se esgotarão a médio prazo. Com o objetivo de selecionar genótipos de milho-pipoca resistentes a h-Bm e com maior capacidade de aproveitamento de fósforo $(\mathrm{P})$, este trabalho avaliou a incidência e a severidade a h-Bm de 25 linhagens (S7) de milho-pipoca, cultivadas em ambientes de alto e baixo fósforo. Houve interação significativa entre genótipo (linhagem) e adubação de P para resistência a h- $B m$, expressa pelos valores de severidade da doença na folha da primeira espiga. Observou-se variabilidade genética quanto à resistência a doença. A análise de incidência identifica as Linhagens L-65 L-69, L-70 e L-76 como genótipos potencialmente resistentes, apresentando baixos valores médios de h- $\mathrm{Bm}$. A avaliação de severidade, no entanto, apresenta como potencialmente resistentes, as linhagens L-69, L-76, P-3 e P-7 tanto em ambiente com adubação de $P$ quanto em ambiente sem a adubação. A união das informações obtidas mostra que as linhagens L-69, L-76 foram as que tiveram melhor desempenho quanto a resistência em ambos os ambientes. Conclui-se que a resistência genética a h- $\mathrm{Bm}$ pode, de algum modo, correlacionar-se com a resposta a adubação de P no plantio, em solos de baixa fertilidade natural.

Palavras-chave: Zea mays; Resistencia genética; Fertilizantes fosfatados.

The agriculture practiced in the tropics is highly dependent on chemical defense and fertilizer application (13). In Brazil, such dependence on fertilization to increase agricultural production is aggravated by the low natural nutrient content, the high acidity and the high phosphorus adsorption capacity of most agricultural and arable lands (7). The natural phosphates used in the composition of fertilizers are produced from non-renewable sources, and P-mineral deposits are expected to be depleted in the next 50 years (9). Thus, 
Table 1. Soil chemistry and particle size analysis of samples from Campos dos Goytacazes.

\begin{tabular}{|c|c|c|c|c|c|c|c|c|c|c|c|c|c|}
\hline \multirow{2}{*}{ Environments } & \multirow{2}{*}{$\begin{array}{c}\mathrm{pH} \\
\mathrm{H}_{2} \mathrm{O} \\
\end{array}$} & \multirow{2}{*}{$\begin{array}{c}P \\
\mathrm{mg} / \mathrm{dm}^{3} \\
\end{array}$} & $\mathbf{K}$ & $\mathrm{Ca}$ & Mg & Al & $\mathrm{Na}$ & $\mathrm{C}$ & OM & CEC & BS & \multirow{2}{*}{$\begin{array}{l}\mathrm{V} \\
\% \\
\end{array}$} & \multirow{2}{*}{$\begin{array}{r}\text { Clay } \\
\text { g/dm } \\
\end{array}$} \\
\hline & & & \multicolumn{5}{|c|}{$\mathbf{m m o l ~ c / d m ^ { 3 }}$} & \multicolumn{2}{|c|}{$\mathrm{g} / \mathrm{dm}^{3}$} & \multicolumn{2}{|c|}{$\mathbf{m m o l ~ c / d ^ { 3 }}$} & & \\
\hline Low P & 6.1 & 8 & 3.7 & 16.6 & 11.7 & 0 & 1.5 & 11.8 & 20.34 & 57.2 & 36.2 & 63 & 305 \\
\hline
\end{tabular}

plant-breeding programs have prioritized the development of superior genotypes capable of more efficiently using the applied phosphorus through mineral fertilization, besides generating plants that are adapted to soils with low natural fertility and that are resistant to the main diseases, with the aim of guaranteeing sustainability in agriculture in the medium and long term.

In Brazil, corn is the most cultivated cereal; in 2016, it was planted in approximately 16,000 hectares, and 83,000 tons of grains were harvested (3). Among "special corns", "popcorn" maize has guaranteed high economic gains in the most diverse branches of the popcorn production chain (15). Popcorn differs from common corn because it has smaller grains, less vigor, greater prolificacy and greater susceptibility to diseases and pests. These latter agents seriously impair popcorn yield and quality $(21,16,20)$.

Considering diseases, popcorn is particularly susceptible to helminthosporiosis ( $\mathrm{h}-\mathrm{Bm}$ ), caused by the fungus Bipolaris maydis (Nisik.) Shoemaker (syn. Helminthosporium maydis) Nisik. \& Myiake. Such diseases have a severe impact on popcorn crops under different management systems and according to the weather conditions (14). For popcorn breeding, similarly to common corn, self-fertilized lineages that advance generations with high genetic depression due to inbreeding are normally used. Popcorn self-fertilized lineages (endogamic) are highly susceptible to $\mathrm{h}-\mathrm{Bm}$. In addition, popcorn synthetic varieties are naturally less resistant to h- $\mathrm{Bm}$ and a larger number of diseases affect popcorn, compared to common maize varieties (12).

The main purpose of popcorn breeding programs is to develop lines resistant to foliar diseases (18), which should be combined with the search for materials tolerant to phosphorus scarcity, the condition of most Brazilian soils (5). Mineral nutrients play specific roles in plant metabolism, affecting their growth and production, as well as the reaction of plants to infectious agents, due to anatomical and biochemical changes (pre and post-formed physical and biochemical barriers) (11). Phosphorus is a macronutrient involved in the constitution of macromolecules and in the activity associated with the plant energy balance (ATP, NADP-H, etc.). The supply of this element guarantees the plant development and directly and indirectly affects the plant nutrition and health. However, for the resistance to the disease, P-mineral is considered to be less expressive than other mineral elements, such as nitrogen, potassium, sulfur, calcium and magnesium (11).

The search for plants more efficient in phosphorus conversion and utilization is of fundamental importance for the development of more productive and resistant cultivars, as well as for plants more tolerant to diseases, reducing the expenses with chemical defense and fertilizers. Therefore, we evaluated the incidence and the severity of helminthosporiosis in leaves of 25 popcorn maize lines grown under high and low phosphorus conditions, in order to obtain a higher level of resistance to $B$. maydis in environments with $\mathrm{P}$ scarcity.

\section{MATERIAL AND METHODS}

Two experiments were carried out at "Colégio Agrícola Estadual Antônio Sarlo", located in Campos dos Goytacazes, Rio de Janeiro State,
Brazil, where geographical coordinates are as follows: $21^{\circ} 42$ ' $48^{\prime \prime} \mathrm{S}$, $41^{\circ} 20^{\prime} 38^{\prime} \mathrm{W}$, and $14 \mathrm{~m}$ altitude. The climate that characterizes Campos dos Goytacazes Municipality is classified as tropical (Aw), showing hot summers, mild winters and rainfall that tends to be concentrated in the summer months.

Before the experiment was performed, the soil chemistry had been analyzed to characterize the phosphorus availability in the soil environments using samples collected at depths of 0-10 and 10-20 cm for characterization of two environments, with high and low phosphorus availability (Table 1). The low phosphorus area was considered that

Table 2. S7 popcorn lines, their respective genealogies, and climate adaptation.

\begin{tabular}{|c|c|c|}
\hline Line & Population origin & Climate adaptation \\
\hline $\mathbf{L 5 3}$ & Beija-flor: UFV & Temperate/ Tropical \\
\hline L54 & Beija-flor: UFV & Temperate / Tropical \\
\hline L59 & Beija-flor: UFV & Temperate / Tropical \\
\hline L61 & BRS Angela: EMBRAPA & Tropical \\
\hline L63 & BRS Angela: EMBRAPA & Tropical \\
\hline L65 & BRS Angela: EMBRAPA & Tropical \\
\hline L66 & BRS Angela: EMBRAPA & Tropical \\
\hline L69 & BRS Angela: EMBRAPA & Tropical \\
\hline L70 & BRS Angela: EMBRAPA & Tropical \\
\hline L71 & BRS Angela: EMBRAPA & Tropical \\
\hline L75 & Viçosa: UFV & Temperate / Tropical \\
\hline L76 & Viçosa: UFV & Temperate / Tropical \\
\hline L77 & Viçosa: UFV & Temperate / Tropical \\
\hline L80 & Viçosa: UFV & Temperate / Tropical \\
\hline L88 & Viçosa: UFV & Temperate / Tropical \\
\hline $\mathbf{P 1}$ & Hybrid Zélia & Temperate / Tropical \\
\hline $\mathbf{P 2}$ & Compound CMS-42 & Temperate / Tropical \\
\hline $\mathbf{P 3}$ & Compound CMS-42 & Temperate / Tropical \\
\hline $\mathbf{P 4}$ & South American Races & Temperate / Tropical \\
\hline P5 & Hybrid Zaeli & Temperate / Tropical \\
\hline P6 & Hybrid Zaeli & Temperate / Tropical \\
\hline P7 & Hybrid Zaeli & Temperate / Tropical \\
\hline P8 & IAC-112 Hybrid & Temperate / Tropical \\
\hline P9 & IAC-112 Hybrid & Temperate / Tropical \\
\hline P10 & IAC-112 Hybrid & Temperate / Tropical \\
\hline
\end{tabular}


with low phosphorus levels, showing values lower than 10 g.dm ${ }^{-3}$ soil (Table 1), according to Sousa and Lobato (19).

Twenty-five popcorn lines $\left(\mathrm{S}_{7}\right)$ from UENF gene bank were evaluated in two contrasting environments considering phosphorus availability: one with low phosphorus availability and the other one with optimal phosphorus availability. Four of these lines were from 'Viçosa' population, four were from 'Beija-Flor' population, seven from 'BRS-Ângela' population, and 10 populations were part of 'UENF' program (Table 2).

Experimental design was in randomized blocks with four replicates. Sowing was performed in conventional tillage. Each plot consisted of a $5 \mathrm{~m}$ line, spaced $0.2 \mathrm{~m}$ between plants, and $0.9 \mathrm{~m}$ between rows, totaling 25 plants per plot.

Fertilization for optimal phosphorus availability consisted of 30 $\mathrm{kg} / \mathrm{ha} \mathrm{N}, 70 \mathrm{~kg} / \mathrm{ha} \mathrm{P}_{2} \mathrm{O}_{5}$, and $40 \mathrm{~kg} / \mathrm{ha} \mathrm{K}_{2} \mathrm{O}$. In the environment with low phosphorus availability, fertilization consisted only of $30 \mathrm{~kg} / \mathrm{ha} \mathrm{N}$ and $40 \mathrm{~kg} / \mathrm{ha} \mathrm{K}_{2} \mathrm{O}$. Topdressing was performed in both environments at a dose of $100 \mathrm{~kg} / \mathrm{ha} \mathrm{N}$, when the plants reached the V6 stage.

Table 3. Joint variance analysis for $\mathrm{h}-\mathrm{Bm}$ incidence and severity in popcorn lines under high and low phosphorus levels.

\begin{tabular}{|c|c|c|c|}
\hline Source of Variation & DF & B. maydis incidence & B. maydis severity \\
\hline Blocks/ environment & 6 & 207.621 & 376.709 \\
\hline Blocks & 3 & 15.767 & 736.811 \\
\hline Blocks $\mathrm{x}$ environment & 3 & 399.475 & 16.606 \\
\hline Lines & 24 & $1585.762 *$ & $1782.330 * *$ \\
\hline Environment & 1 & $10.746^{\mathrm{ns}}$ & $10672.897 * *$ \\
\hline Lines $\mathrm{x}$ environment & 24 & $166.132^{\mathrm{ns}}$ & $1187.183 * *$ \\
\hline Error & 144 & 156.595 & 187.857 \\
\hline Total & 199 & & \\
\hline MEANS & & 73.68 & 30.47 \\
\hline $\mathrm{CV}(\%)$ & & 16.98 & 44.98 \\
\hline
\end{tabular}

Supplementation of primary macronutrients was obtained based on the fertilization recommendation for popcorn culture in both environments, considering a number of nutrients in the soil at the $0-20 \mathrm{~cm}$ layer according to chemical analysis. The low phosphorus environment received no supplementation. Other cultural practices were performed in accordance with the recommendations for this culture in the region. Experiments received supplemental irrigation where necessary to prevent water stress.

The incidence and the severity of h-Bm symptoms were estimated and two methods were adopted: i) assessment of the incidence of the disease symptoms for the whole plant, expressed as percentage, o; and ii) quantification of the severity of symptoms for the whole leaf immediately below the first spike, expressed as percentage. Foliar diseases manifest through natural infection by causal agents in the field. Evaluations were performed by taking six competitive plants per plot at every 7 days from flowering to senescence.

The incidence of h- $\mathrm{Bm}$ symptoms on the plants was estimated with a diagrammatic scale, as adopted by Agroceres (1). The scale ranges from 1 to 9 , wherein $1=0 \%$ incidence; $2=0.5 \%$ incidence; $3=10 \%$ incidence; $4=30 \%$ incidence; $5=50 \%$ incidence; $6=70 \%$ incidence; $7=80 \%$ incidence; $8=90 \%$ incidence; and $9=100 \%$ incidence. To evaluate the severity of h- $\mathrm{Bm}$ on the leaf, we used a diagrammatic scale proposed by James (8), containing the severity ranges in percentage, corresponding to $0,1,5,25$ and $100 \%$ injured leaf area.

Individual and joint variance analysis for environments with high and low phosphorus levels was performed for the two variables, incidence and severity. When the mean effect was significant, average cluster test (Scott-Knott) was performed at 5\% probability (17). All statistical procedures were performed by using the GENES Program (4).

\section{RESULTS AND DISCUSSION}

Joint variance analysis for $\mathrm{h}-\mathrm{Bm}$ incidence showed a significant difference only for the source of variation "line". For environment and line versus environment interaction, no significant difference was observed at $1 \%$ probability level, according to $\mathrm{F}$ test (Table 3). Therefore, for the disease incidence in leaves, averages were compared considering the average data for environments under high

Table 4. Analysis of variance and estimated genetic parameters for Bipolaris maydis incidence and severity in popcorn lines under high and low phosphorus levels.

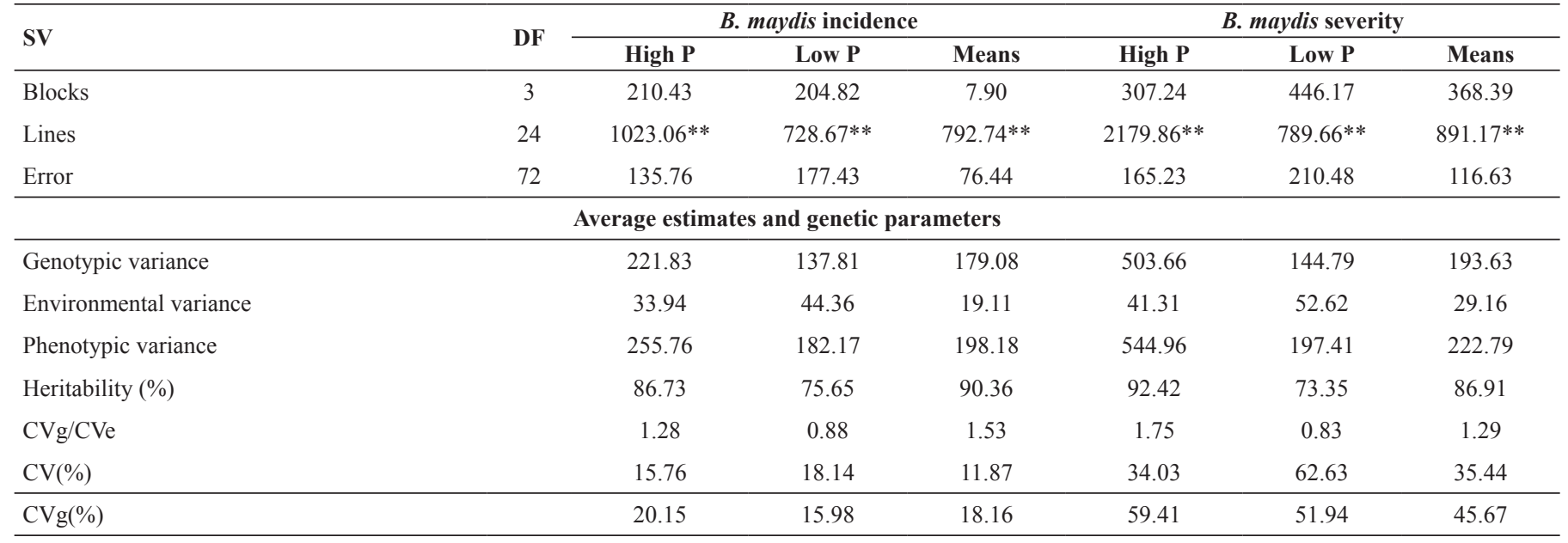

**Significant at 0.01 probability, according to $\mathrm{F}$ test. 
and low phosphorus conditions; since fertilization did not modify the performance of lines for $\mathrm{h}-\mathrm{Bm}$ resistance, no variation observed in the means can be affirmed to be genetic.

The h- $\mathrm{Bm}$ severity analysis indicated significant differences $(\mathrm{p}<0.01)$ for lines, environment and lines versus environment interaction (Table 3). Thus, comparisons of averages occurred within each growing environment, since P-mineral availability in the soil influenced the performance of lines for disease resistance.

Considering the results obtained for h- $\mathrm{Bm}$ incidence and severity, and the need to compare means in each environment alone and jointly, analysis of individual variance was carried out, considering the average of the two environments, as well as each environment separately. Significant effects on the lines were observed, in both environments, which shows that genetic control is apparently differentiated in both situations (Table 4).
Coefficients of variation (CV) ranged from 15.98 to 20.15 for the incidence and from 44.98 to 59.41 for the severity of $B$. maydis (Tables 3 and 4). These data were in agreement with those reported by Arnhold (2), who observed coefficients of variation of $17.8 \%$ for $\mathrm{h}-\mathrm{Bm}$ incidence, considering an average value for field experimentation which, according to Ferreira (6), demonstrates good data accuracy, since CV values are between 15 and $20 \%$.

Based on the estimates of genetic parameters, much of the phenotypic variance observed in the studied lines is genetically controlled, not by chance heritability magnitudes were higher than $70 \%$ (Table 4). For the leaf disease incidence estimated based on the average of the two environments (non-significant lines versus environment interaction), heritability was $90.36 \%$. For h- $B m$ severity, the lines versus environments interaction was significant; higher heritability (92.42) was observed in the environment with P-mineral fertilization (Table 4),

Table 5. Averages of incidence of Bipolaris maydis symptoms and disease severity based on the leaf below the first ear, evaluated in popcorn lines grown under high and low phosphorus levels.

\begin{tabular}{|c|c|c|c|c|c|c|c|c|c|c|c|c|}
\hline \multirow{3}{*}{$\begin{array}{l}\text { Lines } \\
\text { L-53 }\end{array}$} & \multicolumn{6}{|c|}{ B. maydis incidence } & \multicolumn{6}{|c|}{ B. maydis severity } \\
\hline & \multicolumn{2}{|c|}{ High P } & \multicolumn{2}{|c|}{ Low $P$} & \multicolumn{2}{|c|}{ Means } & \multicolumn{2}{|c|}{ High P } & \multicolumn{2}{|c|}{ Low P } & \multicolumn{2}{|c|}{ Means } \\
\hline & 90.83 & A & 72.22 & A & 81.53 & $\mathrm{~A}$ & 75.50 & $\mathrm{~B}$ & 46.47 & A & 60.99 & A \\
\hline L-54 & 84.17 & A & 88.54 & A & 86.35 & A & 92.68 & A & 19.70 & B & 56.19 & A \\
\hline L-55 & 53.34 & B & 75.65 & A & 64.49 & B & 85.00 & $\mathrm{~A}$ & 15.02 & B & 50.01 & B \\
\hline L-59 & 75.84 & A & 73.06 & A & 74.45 & B & 33.82 & $\mathrm{C}$ & 21.11 & B & 27.47 & $\mathrm{C}$ \\
\hline L-61 & 65.83 & A & 69.17 & A & 67.50 & $\mathrm{~B}$ & 31.33 & $\mathrm{C}$ & 20.84 & B & 26.09 & $\mathrm{C}$ \\
\hline L-63 & 68.61 & A & 76.11 & A & 72.36 & B & 63.49 & B & 13.48 & B & 38.48 & B \\
\hline L-65 & 28.47 & $\mathrm{C}$ & 31.95 & $\mathrm{C}$ & 30.21 & $\mathrm{D}$ & 13.63 & $\mathrm{D}$ & 47.13 & A & 30.38 & $\mathrm{C}$ \\
\hline L-66 & 79.72 & A & 83.61 & A & 81.67 & A & 30.86 & $\mathrm{C}$ & 20.38 & B & 25.62 & $\mathrm{C}$ \\
\hline L-69 & 39.17 & $\mathrm{C}$ & 55.00 & B & 47.08 & $\mathrm{C}$ & 8.41 & $\mathrm{D}$ & 2.88 & B & 5.64 & D \\
\hline L-70 & 48.75 & $\mathrm{~B}$ & 55.33 & B & 52.04 & $\mathrm{C}$ & 47.35 & $\mathrm{C}$ & 3.98 & B & 25.67 & $\mathrm{C}$ \\
\hline L-71 & 79.72 & A & 81.39 & A & 80.56 & A & 35.13 & $\mathrm{C}$ & 10.70 & B & 22.92 & $\mathrm{C}$ \\
\hline L-76 & 65.56 & A & 52.22 & B & 58.89 & $\mathrm{C}$ & 8.35 & $\mathrm{D}$ & 5.96 & B & 7.16 & D \\
\hline L-77 & 88.89 & A & 88.89 & A & 88.89 & A & 70.95 & B & 53.31 & A & 62.13 & A \\
\hline $\mathrm{L}-80$ & 91.11 & A & 97.50 & A & 94.31 & A & 20.39 & $\mathrm{D}$ & 37.00 & A & 28.70 & $\mathrm{C}$ \\
\hline L-88 & 89.17 & A & 78.06 & A & 83.61 & A & 29.93 & $\mathrm{C}$ & 37.10 & A & 33.51 & $\mathrm{C}$ \\
\hline P-1 & 82.78 & A & 79.44 & A & 81.11 & A & 47.65 & $\mathrm{C}$ & 43.78 & A & 45.71 & B \\
\hline $\mathrm{P}-2$ & 80.56 & A & 76.39 & A & 78.47 & A & 28.38 & $\mathrm{C}$ & 13.23 & B & 20.80 & $\mathrm{C}$ \\
\hline P-3 & 75.00 & A & 71.11 & A & 73.06 & B & 14.89 & $\mathrm{D}$ & 20.07 & B & 17.48 & D \\
\hline $\mathrm{P}-4$ & 83.61 & A & 66.67 & A & 75.14 & B & 41.03 & $\mathrm{C}$ & 11.89 & B & 26.46 & $\mathrm{C}$ \\
\hline P-5 & 80.84 & A & 79.72 & A & 80.28 & A & 27.20 & $\mathrm{C}$ & 18.98 & B & 23.09 & $\mathrm{C}$ \\
\hline P-6 & 80.00 & A & 79.17 & A & 79.58 & A & 42.50 & $\mathrm{C}$ & 32.55 & A & 37.53 & B \\
\hline P-7 & 74.72 & A & 70.00 & A & 72.36 & $\mathrm{~B}$ & 13.27 & $\mathrm{D}$ & 12.01 & B & 12.64 & D \\
\hline P-8 & 79.16 & A & 81.39 & A & 80.28 & A & 26.13 & $\mathrm{C}$ & 26.88 & B & 26.51 & $\mathrm{C}$ \\
\hline P-9 & 81.11 & A & 77.23 & A & 79.17 & A & 28.54 & $\mathrm{C}$ & 22.17 & B & 25.36 & $\mathrm{C}$ \\
\hline P-10 & 80.83 & A & 76.39 & A & 78.61 & A & 28.03 & $\mathrm{C}$ & 22.54 & B & 25.29 & $\mathrm{C}$ \\
\hline Average & 73.62 & & 73.32 & & 73.47 & & 38.18 & & 23.19 & & 30.69 & \\
\hline
\end{tabular}

*For the same variable, means followed by the same letter consist of a homogeneous group, according to Scott-Knott test at $5 \%$ probability. 
while in the environment without P-mineral fertilization heritability was $73.35 \%$. Arnhold (2) evaluated B. maydis in S1 popcorn families and obtained heritability of 0.5 , while Marcos et al. (10) evaluated h- $B m$ in Panicum maximum hybrids and obtained values of $87.19 \%$ and $83.89 \%$. These values indicate that the selection process of these materials will be efficient, and the adopted scales are effective for the most favorable genotypes to reduce the incidence and the severity values.

Four groups were formed for B. maydis incidence according to the cluster test (Scott-Knott), independent of fertilization (Table 5). The group that presented the lowest incidence value contained only one line, L-65, with values of 30.21, considered resistant when compared to the other lines. For group C, L-69, L-70 and L-76 were considered moderately resistant, showing incidence values of $47.08,52.04$ and 58.89 , respectively.

Considering the severity of h- $B m$ symptoms, four groups were formed in the environment with P-mineral fertilization and two groups were formed in the environment without fertilization (Table 5). The lines L-69, L-76, P-3 and P-7 showed lower h- $\mathrm{Bm}$ severity averages in both environments. The lines L-69 and L-76 were distinguished from the others because they presented low severity levels in both environments and there were lines resistant to the disease incidence and severity.

The lines L-69 and L-76 are promising for h- $\mathrm{Bm}$ resistance in both environments. Additional studies in natural soil with low fertility and under low P-mineral conditions have demonstrated the great need to obtain productive and resistant lines, given the large number of areas with low phosphorus in the country. In addition, considering that L-69 was originated from BRS Ângela and L-76 from Viçosa, these crossbreeding lines can generate promising hybrids since they are lines of distinct origins and populations that suffer from a strong endogamy effect.

P-mineral availability in the soil influenced the performance of lines for h- $B m$ resistance. Thus, there is the possibility of selecting materials in different environments.

The evaluated variables, severity and incidence, indicated that the most resistant lines to h- $\mathrm{Bm}$, considering both environments under the experimental conditions of the present study, are L-69 and L-76.

\section{REFERENCES}

1. Agroceres. Guia Agroceres de sanidade. São Paulo: Sementes Agroceres, 1996. 72p.

2. Arnhold, E. Seleção para resistência a doenças foliares em famílias S1 de milho-pipoca. Revista Ceres, Viçosa, v.55, n.2, p.89-93, 2008.

3.Companhia Nacional de Abastecimento - CONAB. Levantamento da produtividade de milho 2016. Brasília, 2016: Disponível em https://www. conab.gov.br/info-agro/safras/graos/boletim-da-safra-de-graos/item/download/1309_e50ecf243ee7243e60da214f4fdefed3>. Acesso em: 26 set. 2016.
4. Cruz, C.D. GENES - a software package for analysis in experimental statistics and quantitative genetics. Acta Scientiarum Agronomy, Maringá, v.35, p.271-276, 2013.

5. Durães, F.O.M.; Santos, M.X.; Gama, E.E.G; Magalhães, P.C.; Albuquerque, P. E.P.; Guimarães, C.T. Fenotipagem associada a tolerância a seca em milho para uso em melhoramento, estudos genômicos e seleção assistida por marcadores. Sete Lagoas MG: Embrapa, 2004. (Circular Técnica, 39).

6. Ferreira, P.V. Estatística experimental aplicada à agronomia. Maceió: EDUFAL, 1991.

7. Hopkins, B.; Ellsworth, J. Phosphorus availability with alkaline/calcareous soil. In: Western Nutrient Management Conference, Proceedings. Salt Lake City UT, 2005. Vol 6, p.88-93. Disponivel em: <http://isnap.oregonstate. edu/WERA_103/2005_Proccedings/Hopkins\%20Phosphorus\% 20pg88. pdf>. Acesso em: 26 set. 2016.

8. James, W.C. A manual of assessment keys for plant diseases. St. Paul: The American Phytopathologycal Society, 1971. 66p.

9. Malavolta, E. Manual de nutrição mineral de plantas. São Paulo: Editora Agronomica Ceres, 2006. 638p.

10. Marcos, M.F.; Jank, L.; Fernandes, C.D.; Verzignassi, J.R.; Mallmann, G.; Queiroz, C.A.; Batista, M.V. Reação à Bipolaris maydis, agente causal da mancha foliar, em híbridos apomíticos de Panicum maximum. Summa Phytopathologica, Botucatu, v.41, n.3, p.197-201, 2015. DOI: doi. org/10.1590/0100-5405/2078

11. Marschner, $H$. Mineral nutrition of higher plants. 2nd ed. New York: Academic, 1995. 889p.

12. Oliveira, E.; Fernandes, F.T.; Casela, C.R.; Pinto, N.F.J.A.; Ferreira, A.S. Diagnose e controle de doenças na cultura do milho. In: Galvão, J.C.C.; Miranda, G.V. Tecnologias de produção do milho: economia, cultivares, biotecnologia, safrinha, adubação, quimigação, doenças, plantas daninhas e pragas. Viçosa: Editora UFV, 2004. p.227-268.

13. Roel, A.R.A agricultura orgânica ou ecológica e a sustentabilidade da agricultura. Revista Internacional de Desenvolvimento Local, Campo Grande, v.3, n.4, p.57-62, 2002.

14. Reis, E.M.; Casa, T.; Bresolin, A.R. Manual de diagnose e controle de doenças do milho. Passo Fundo, 2004. 141p.

15. Rangel, R.M.; Amaral Júnior, A.T.; Viana, A.P.; Freitas Júnior, S.P.; Pereira, M.G. Prediction of popcorn hybrid and composites means. Crop Breeding and Applied Biotechnology, Viçosa, v.7, n.3, p.287-295, 2007.

16. Sawazaki, E. A cultura do milho pipoca no Brasil. O Agronômico, Campinas, v.53, n.2, p.11-13, 2001.

17. Scott, A.; Knott, M. Cluster-analysis method for grouping means in analysis of variance. Biometrics, Washington, DC, v.30, n.3, p.507-512, 1974

18. Silveira, F.T.; Junqueira, B.G.; Silva, P.C.; Moro, J.R. Comportamento de linhagens elites de milho para resistência aos enfezamentos. Revista Brasileira de Milho e Sorgo, Sete Lagoas, v.5, p.431-442, 2006.

19. Sousa, D.M.G.; Lobato, E. Adubação com nitrogênio. In: Sousa, D.M.G.; Lobato, E. Cerrado: correção do solo e adubação. Planaltina: Embrapa Cerrados, 2004. p.129-144.

20. Vieira, R.A; Tessmann, D.J.; Hata, F.T.; Souto, E.R.; Mesquini, R.M. Resistência de híbridos de milho-pipoca a Exserohilum turcicum, agente causal da Helmintosporiose Do Milho. Scientia Agraria, Curitiba, v.10, n.5, p.391-395, 2009.

21. Zinsly, J.R.; Machado, J.A. Milho-pipoca. In: Paterniani, E.; Viégas, G.P. Melhoramento e produção do milho. 2.ed. Campinas: Fundação Cargill, 1987. p.413-421. 